\title{
SINISME PRIVASI, DISKRIMINASI DAN KOMODITAS DATA: PARADOKS MEDIA SOSIAL DI ERA KAPITALISME PENGAWASAN
}

\author{
Titis Nurwulan Suciati \\ Universitas Bhayangkara Jakarta Raya \\ Email: titis.nurwulan@dsn.ubharajaya.ac.id
}

\begin{abstract}
ABSTRAK
Terinspirasi dari banyak kasus penyelewengan data Facebook yang digunakan untuk kepentingan politik dan kekuasaan, tulisan berikut mencoba memetakan secara kritis konsep dan tidak pengawasan di ranah digital khususnya media sosial serta konsekuensi sosial yang "tak terlihat" pada penggunanya, dengan alasan media sosial adalah aplikasi internal yang sangat popular dan mengambil bagian dalam kehidupan sehari-hari masyarakat. Perkembangan cepat perangkat seluler menandai merayapnya pengawasan secara progresif ke dalam kehidupan sehari-hari dengan memungkinkan pengguna untuk ditemukan dan dilacak yang pada akhirnya mengubah perilaku sosial mereka. Pada saat yang sama, kekuatiran ini tampaknya tidak menghasilkan gelombang perilaku perlindungan yang sesuai. Dalam penelitian yang menggunakan metode tinjauan literatur sistematik ini, penulis menggarisbawahi bahwa platform media sosial memungkinkan pengguna warga negara untuk saling berkomunkasi, berbagi informasi dengan pengguna lain, termasuk perincian data pribadi mereka sendiri. Sementara, aktor negara dan perusahaan memiliki potensi untuk mengawasi dan mengintervensi platform ini. Konsekuensi sosial tidak hanya hilangnya privasi, tetapi juga diskriminasi, penyortiran sosial dan komodifikasi data. Pada media sosial, pengguna merasa bahwa konten mereka bersifat pribadi, meskipun secara teknis, tidak. Pelaku pengawasan sendiri memandang media sosial sebagai ruang publik.Dengan kemunculan konsekuensi sosial tersebut, penulis meminjam pemikiran Fuchs untuk perlunya pengawasan masyarakat sipil terhadap perusahaan internet, dan pembentukan dan dukungan platform alternative sebagai kontra pengawasan yang tidak simetris yang dilakukan oleh raksasa-raksasa digital seperti Facebook dan Google.
\end{abstract}

Kata Kunci: Pengawasan, Media Sosial, Privasi, Digital, Komodifikasi, Diskriminasi

PENDAHULUAN

Skandal Facebook yang
melibatkan Cambridge Analytica
Maret 2018 silam membuat Facebook
kelabakan menghadapi kemarahan dan
kecaman banyak pihak. Cambridge

terbukti memanen dan memanfaatkan data jutaan pengguna Facebook untuk kepentingan politik. Facebook semakin terpojok dengan dibeberkannya fakta bahwa, Facebook telah menyimpan catatan panggilan 
dan teks pemakai Android. Permintaan maaf dari CEO Facebook,Mark Zuckerberg sistem kerja perusahaan raksasa tersebut.

Namun laporan terbaru Times akhir 2018 mengulang mimpi buruk pengguna Faceook Seolah deja vu skandal privasi Facebook yang luarbiasa, Investigasi New York Times menemukan bukti Facebook memberi kuasa bagi Netflix, Spotify dan Royal Bank of Canada (RBC) untuk membaca, menulis, dan menghapus pesan pribadi pengguna. Microsoft, Sony dan Amazon, misalnya, dapat memperoleh informasi kontak teman-teman penggunanya (New York Times, 18/12/2018).

\section{Pelaporan The Times}

membuka sebuah jendela kesadaran akan adanya pengawasan dan logika ekonomi yang muncul dari “kapitalisme pengawasan.” Kita mulai melihat bagaimana perdagangan data banyak yang dilakukan di belakang layar - juga merupakan pertukaran pengaruh dan kekuasaan. Dalam era digital seperti sekarang, semua data berpotensi berguna. Bahkan perusahaan mobil ternama Ford dengan keras gembar-gembor data konsumen sebagai aliran pendapatan utama yang setara dengan penjualan mobil.

Andrews (2011) dalam bukunya yang berjudul "I know who you are and I saw what you did" menyatakan media sosial memiliki manfaat yang menakjubkan. Orangorang masuk Facebook mungkin untuk kebebasan komunikasi, menyalurkan ekspresi, dan untuk mengembangkan potensi diri. Namun, media sosial menyediakan ruang bagi penggunanya untuk melakukan pengawasan kepada pengguna lainnya. Pengguna ini bisa saja individu, perusahaan, organisasi atau bahkan negara. Implikasi dari hal ini cukup besar dalam mempengaruhi kehidupan masyarakat. Dampak ini ini tidak hanya pada privasi tetapi pada berbagai hak - tapi juga otonomi dan kebebasan di hampir setiap aspek kehidupan pengguna.

$\begin{array}{rrrr}\text { Menurut } & \text { Agus } & \text { Sudibyo, } \\ \text { dikutip dari } & \text { Harian } & \text { Kompas }\end{array}$ (4/4/2018) kita sedang menghadapi campur tangan dan pengendalian atas kehidupan pribadi pengguna medsos. Menurutnya, pengguna media sosial umumnya tidak menyadari campur tangan pengendalian tersebut. Kata sosial dalam media sosial begitu hegemonic sehingga masyarakat umumya mengira media sosial murni 
ruang diskusi dan interaksi sosial. Masyarakat tidak menyadari media sosial juga merupakan pengawasan yang dilakukan perusahaan media digital.

Tulisan ini mengambil fokus tindak pengawasan di media sosial serta konsekuensi sosial yang "tak terlihat" pada penggunanya, dengan alasan media sosial adalah aplikasi internal yang sangat popular dan mengambil bagian dalam kehidupan sehari-hari masyarakat. Pada Mei 2013, Facebook melaporkan bahwa 4,75 miliar keping konten dibagikan setiap hari (Facebook 2013). Pada saat yang sama, dilaporkan ada rata-rata 400 juta tweet diposting setiap hari (Twitter 2013). Di awal 2014, ada lebih dari 1,15 miliar pengguna Facebook, 1 miliar diaktifkan Akun Google+ (walaupun wajib disiapkan bila terkait dengan Google lainnya akun dibuat), 550 juta pengguna terdaftar di Twitter, dan dua situs berbagi gambar, Pinterest dan Instagram, memiliki lebih dari 20 juta dan 150 juta pengguna bulanan aktif masing-masing. Saat itu, 72\% dari semua internet pengguna diklaim aktif di media sosial, dengan angka itu naik menjadi $89 \%$ di antara anak-anak berusia 18-29 tahun, dan masih setinggi $60 \%$ di antara anak-anak berusia 50-60 tahun (Bullas 2014). Buletin statistik tentang akses internet yang diproduksi oleh Kantor Statistik Nasional (ONS) di Inggris melaporkan bahwa, pada $2013,73 \%$ orang dewasa di Inggris mengakses internet setiap hari (ONS 2013). Dengan angka itu naik setinggi 93\% untuk usia 16-24 tahun. Dan di sampingnya platform dominan ini (yang juga mencakup LinkedIn, YouTube dan Flickr), ada banyak platform yang kurang terkenal.

\section{METODOLOGI}

Penelitian ini menggunakan pendekatan kualitatif dan metode studi literatur. Data yang digunakan sebagai bahan analisis yakni artikel-artikel di berbagai jurnal. Dalam penelitian yang menggunakan metode tinjauan literature sistematik ini, data yang digunakan dapat dibagi menjadi dua. Pertama, artikel atau karya ilmiah yang memuat konsep pengawasan media sosial sebagai pembahasan utamanya; kedua, artikel-artikel lepas nonsaintifik yang membahas konsep pengawasan di ranah media sosial.

Data pertama penulis kumpulkan dari hasil pencarian Google Scholar dengan alasan bahwa website tersebut memungkinkan hasil 
pencarian artikel dari beragam jurnal, tidak dibatasi oleh penerbitannya. Artikel yang dimuat di jurnal yang diterbitkan Sage, misalkan, akan dapat bersanding dengan artikel yang diterbitkan oleh Jstor pada hasil pencarian Google Scholar. Dengan demikian, penulis tidak perlu masuk ke masing-masing halaman penerbit untuk melakukan pencarian. Pada tab filter pencarian lanjutan (advance), penulis memasukkan kata kunci "surveillance", "social media "paradox" dan "consequences", dengan rentang dari tahun 2010 hingga 2019. Selain itu, Penulis menggunakan kerangka pemikiran terkait pengawasan kapitalisme Suzanna Zuboff (2015) dan Hellen Kennedy (2016).

\section{PEMBAHASAN}

Gary T. Marx mendefinisikan pengawasan baru sebagai "penggunaan sarana teknis untuk mengekstraksi atau membuat data pribadi. Ini dapat diambil dari individu atau konteks "(Marx 2002, 12). Dia berpendapat bahwa dalam surveilans lama, lebih sulit untuk mengirim data, sedangkan dalam pengawasan baru ini lebih mudah. Dalam pengawasan tradisional, "apa yang diketahui surveilant, subjek mungkin juga tahu", sedangkan dalam surveilans baru "surveillant mengetahui hal-hal yang tidak diketahui subjek" (Marx 2002, 29). Dia mengatakan bahwa pengawasan baru tidak di tempat, tetapi jauh, dan bahwa itu "kurang koersif"(28) dan "lebih demokratis" karena beberapa bentuk lebih luas tersedia. Pengawasan terkomputerisasi adalah bentuk penting dari pengawasan baru. "Komputer secara kualitatif mengubah sifat pengawasan - merutekanisasi, memperluas, dan memperdalamnya. (Marx 1988, 208).

Studi pengawasan baru mendapat sorotan banyak pemikir, satu sama lain meyumbang istilah yang berbeda untuk melabeli kegiatan pengawasan baru tersebut (Clarke 1988,500) memakai istilah datavaillance dengan pengertian "Pemantauan sistematis atas tindakan atau komunikasi orang melalui penerapan teknologi informasi" (Clarke 1988, 500). Clarke (1994) lalu membedakan antara pengawasan data pribadi yang memonitor tindakan satu atau lebih orang dan pengawasan data massal, di mana suatu kelompok atau populasi besar dimonitor untuk mendeteksi ketertarikan individu. Gordon (1987) berbicara tentang 
panoptikon elektronik. Mark Poster (1990) telah menciptakan gagasan superpanopticon elektronik: "'sirkuit komunikasi' hari ini dan basis data yang mereka hasilkan membentuk Superpanopticon, sistem pengawasan tanpa dinding, jendela, menara atau penjaga" (Poster 1990, 93). Mark Andrejevic melahirkan istilah yang fenomenal berupa gagasan kandang digital (Andrejevic 2004, 2007). Menurutnya, teknologi interaktif menghasilkan "umpan balik tentang transaksi itu sendiri", dan dia mengatakan bahwa umpan balik ini "menjadi milik perusahaan swasta" (Andrejevic 2007, 3). Pengawasan komersial dan negara menjadi hasil dari kandang digital. Pengawasan semacam ini menghasilkan hubungan kekuasaan yang asimetris dan tidak demokratis. (Andrejevic 2007, 257). Klaim Andrejevic ini tentu bersebrangan dengan gagasan Marx akan pengawasan baru dimana pengawasan baru "lebih demokratis" ketimbang pengawasan lama.

Analisis lainnya, David Lyon menawarkan gagasan pengawasan elektronik: "Pengawasan kontemporer harus dipahami dalam terang keadaan yang berubah, terutama meningkatnya pusat konsumsi dan adopsi teknologi informasi" (Lyon 1994, 225). Lyon menekankan peran komputer untuk pengawasan kontemporer. Menurutnya, pengawasan kontemporer harus dipahami dalam terang keadaan yang berubah, terutama meningkatnya pusat konsumsi dan adopsi teknologi informasi" (Lyon 1994, 225).

"Pengawasan elektronik berkaitan dengan cara-cara database komputer digunakan untuk menyimpan dan memproses informasi pribadi tentang berbagai jenis populasi" (Lyon 1994, 8). David Lyon (1998; 2001, 101) berbicara tentang web pengawasan di seluruh dunia untuk menekankan bahwa "semua penggunaan Internet, web di seluruh dunia dan sistem email dapat dilacak dan kapasitas ini dengan cepat dieksploitasi ketika media ini dikomersialkan" Lyon membagi tiga bentuk utama pengawasan di dunia maya yang terkait dengan pekerjaan, keamanan dan kepolisian, dan pemasaran (Lyon 1998, 95). Lyon (1994, 51f) berkata digitalisasi dan jaringan telah mengubah pengawasan: ukuran file telah bertambah, individu dapat lebih mudah dilacak karena basis data tersebar dan mudah diakses oleh lembaga pusat, kecepatan arus data 
telah meningkat, dan warga Negara semakin menjadi sasaran pemantauan yang semakin konstan dan mendalam.

Ericson (2000/2007) telah memperkenalkan gagasan surveillant berkumpul dan berargumen bahwa pengawasan kontemporer adalah heterogen, melibatkan manusia dan non-manusia, lembaga negara dan ekstra-negara, dan "Memungkinkan untuk pengawasan yang kuat oleh institusi dan populasi secara umum "(Haggerty dan Ericson 2000/2007, 112). Lyon (1994, 26, 67). Sementara itu, Castells menganggap pengawasan internet sebagai teknologi kontrol (Castells 2001, 171). Castell mengatakan, "Tracking of communication flows from a specifi $c$ computer location, and monitor machine activity around the clock. Surveillance technologies may identify a given server at the origin of a message." negara, perusahaan atau pengadilan mendapatkan data dari penyedia layanan internet identitas pelaku yang potensial. Web 2.0 pengawasan diarahkan pada kelompok pengguna besar yang membantu secara hegemonic memproduksi dan mereproduksi pengawasan dengan menyediakan konten yang dihasilkan pengguna (diproduksi sendiri). Karena itu, pengawasan web 2.0 sebagai pengawasan diri massal.

Suzanna Zuboff

menawarkan istilah lain akan pengawasan kontemporer yang ia namakan kapitalisme pengawasan. Kapitalisme pengawasan bagianda dari kapitalisme yang sepenuhnya baru di mana keuntungan berasal dari pengawasan sepihak dan modifikasi perilaku manusia "(Zuboff, 2016, 1). Zuboff (2015) berpendapat bahwa kapitalisme pengawasan merupakan "logika akumulasi yang muncul" dari jejak digital, sebuah rezim baru yang muncul dari mediasi komputer yang meluas dan yang "menghasilkan hubungan sosial sendiri dan konsepsi dengan menggunakan otoritas dan kekuasaan "

Namun tidak semua peneliti bernada negatif terhadap perkembangan pengawasan di internet, beberapa pemikir netral dalam memandang pengawasan. Menurut aliran ini, pengawasan tidak selalu menyiratkan pemaksaan, dominasi bahkan penindasan. Pendukung pengawasan netral, ini fokus pada pengumpulan, penyimpanan pemrosesan, dan transmisi informasi tentang individu, kelompok, massa, atau lembaga, 
terlepas dari konteks, motivasi dan konsekuensi pengawasan. Mereka juga tidak merujuk pada tujuan pengawasan dan kepentingan di balik pengawasan (lihat misalnya Ball / Webster 2003 Solove 2004, 42; Bogard 2006, 101; Bogolikos 2007, 590).

Salah satu toloknya, Albrechtslund menggunakan istilah pengawasan pastisipasif karena praktik jejaring sosial terdapat unsur kerelaan terlibat dengan yang lain orang dan membangun identitas, dan dengan demikian dapat digambarkan sebagai partisipatif. Namun demikian, untuk berpartisipasi dalam jejaring sosial online juga tentang tindakan berbagi diri kita — atau identitas kita yang dibangun - dengan orang lain. Dalam hal ini, pengawasan partisipatif adalah cara untuk mempertahankan pertemanan dengan mengawasai informasi yang dibagikan orang lain "(Albrechtslund 2008).

Media sosial, secara kasar didefinisikan sebagai "sekelompok aplikasi berbasis Internet yang dibangun di atas dasar ideologis dan teknologi Web 2.0, dan yang memungkinkan penciptaan dan pertukaran konten yang dibuat pengguna" (Kaplan dan Haenlein 2010: 0), membentuk lapisan online baru di mana orang mengatur hidup mereka. Awalnya, kebutuhan akan keterhubungan inilah yang mendorong banyak pengguna ke situs-situs ini. Dijk (2013) mengatakan, ketika Web 2.0 pertama kali menyusun perkembangan yang disebut media sosial, pada tahun-tahun awal milenium baru, budaya partisipatif adalah kata kunci yang menghubungkan potensi Web untuk memelihara koneksi, membangun komunitas, dan memajukan demokrasi. Banyak platform merangkul semangat yang dihidupkan kembali ini ketika mereka mulai membuat Web "lebih sosial."

Boyd (2019) menjelaskan media sosial sebagai kumpulan perangkat lunak yang memungkinkan individu maupun komunitas untuk berkumpul, berbagi , berkomunikasi, dan dalam kasus tertentu saling berkolaborasi atau bermain. Media sosial memiliki kekuatan pada usergenerated content (UGC) dimana konten dihasilkan oleh pengguna, bukan oleh editor peeti halnyadi media massa mainstream. Dalam publikasi selanjutnya, pada 2013, Ellison dan Boyd mencatat bahwa media sosial 
telah berevolusi secara dramatis sejak definisi awal itu: beberapa fitur miliki penurunan signifikansi, beberapa telah diadopsi oleh genre online lainnya, dan telah ada penggabungan umum SNS dan platform lainnya Saling terhubung dan bertukar data dengan API terbuka. Van Dijck (2013) mengacu pada definisi media sosial dari Kaplan dan Haenlein (2010). Menurut Kaplan dan Haenlein, media sosial adalah 'sebuah kelompok aplikasi berbasis Internet yang dibangun di atas ideologis dan teknologi fondasi Web 2.0, dan yang memungkinkan pembuatan dan pertukaran konten yang dibuat pengguna '(2010, hlm. 60; dikutip dalam van Dijck 2013a, hlm. 4). Dalam definisi ini,, keempat jenis media sosial ini dapat diidentifikasi sebagai berikut:

- Situs jejaring sosial (SNS), yang, seperti pendapat Boyd dan Ellison, mempromosikan kontak dan komunikasi antarpribadi seperti Facebook, Twitter, LinkedIn dan Google+.

- Situs konten yang dibuat pengguna (UGC), yang mempromosikan pertukaran

konten kreatif yang diproduksi oleh amatir dan profesional seperti
YouTube, Flickr, Instagram, dan Wikipedia.

- Situs perdagangan dan pemasaran (TMS) untuk bertukar atau menjual produk, seperti Amazon, eBay atau Craigslist

- Situs bermain dan game (PGS) seperti Farmville, The Sims dan Angry Bird.

Facebook adalah 'wadah bocor' begitu Lyon (2001) menyebutnya. Data informasi seperti aliran keluar yang merembes adalah kejadian umum. Lyon berargumen, bahwa perkembangan cepat perangkat seluler menandai merayapnya pengawasan secara progresif ke dalam kehidupan sehari-hari dengan memungkinkan pengguna untuk ditemukan dan dilacak. Webcam (Koskela 2006) dan media sosial (Albrectslund 2008) memungkinkan visibilitas yang diberdayakan. Namun penggunaan sukarela dari pengguna ini menambah tindak pengawasan di mana totalitas kehidupan sehari-hari terlihat oleh bisnis dan pemerintah (Andrejevic 2007). Dengan jumlah pengguna yang terus berkembang pesat, serta melimpahnya informasi tentang diri mereka sendiri, perusahaan menjadi sangat bersemangat untuk 
memanfaatkan dan mengeksploitasi tambang emas informasi ini.

Satu abad yang lalu, sumber daya yang terbesar adalah minyak.Sekarang kekhawatiran serupa ditujukan kepada mereka, raksasaraksa teknologi yang menangani data, minyak era digital. "Big Brother" tersebut adalah Google, Amazon, Apple, Facebook, dan Microsoft. Ponsel pintar dan internet telahmembuat data berlimpah, tersebar di mana-mana dan jauh menjadikannya sangat berharga. Internet yang mulanya ditujukan bukan untuk komersial, lambat laun berubah. Facebook contohnya. Pengawasan di Facebook meluas dari upaya sebelumnya untuk mengumpulkan data dalam skala besar (Elmer 2004).

Pada satu sisi, tentang bagaimana internet membawa kemudahan dan meningkatkan kualitas kehidupan masyarakat tentulah tidak lagi diragukan. Namun di sisi lain, semua kemungkinan itu menimbulkan kekuatiran baru. Sependapat dengan tindakan mengungkapkan diri di media sosial seperti dengan membagi informasi pribadi, memposting peristiwa dan kegiatan yang dilakukannya menempatkan privasi seseorang dalam risiko. Dalam konteks media sosial seperti di atas, risiko privasi erat kaitannya dengan tindakan pengungkapan diri atau yang disebut Jourard (1971) sebagai tindakan berbagi informasi pribadi dengan orang atau lembaga lain secara sengaja. Oleh karena itu, penanganan privasi di web sosial telah menjadi topik penting di media dan masyarakat. Masalah privasi dan pengawasan telah meningkat (Barnes 2006; Paine et Al. 2006; Lampe et al. 2007; Lewis et al. 2008; Krämer and Winter 2008; Thelwall 2008; Tufekci 2008; boyd dan Hargittai 2010).

Setidaknya tiga jenis masalah privasi telah muncul dalam konteks situs jejaring sosial. Pertama, dimulai dengan individu memposting informasi tentang diri mereka sendiri; kemudian, ketika informasi ini ditemukan, itu membuat mereka mendapatkan masalah dan kesulitan. Beberapa kajian dan penelitian beberapa tindakan pengungkapan diri di media sosial yang pada akhirnya menempatkan diri mereka pada situasi yang bahaya. Resiko utama yang diungkapkan Brake (2014) adalah predator seksual dan cyberbullying. Dari tulisan yang dilansir $\mathrm{CNN}$ Indonesia (04/03/2019), National 
Society for the Prevention of Cruelty to Children (NSPCC) menemukan Instagram jadi media sosial favorit predator anak untuk mencari korban seksual mereka. LSM Kemanusiaan Inggris ini menemukan pedofil menggunakan Instagram untuk berkomunikasi dengan anak-anak. Pada 2017, masyarakat Indonesia juga pernah dikejutkan dengan adanya pengungkapan Official Loly Candy's Groups 18+ di Facebook yang mempromosikan pedofilia. Berbagai konten bermuatan pelecehan dan pencabulan anak beredar dalam grup beranggotakan 7.497 orang.

Tipe kedua dari masalah privasi yang muncul dari jejaring sosial dimunculkan oleh praktik memposting konten tentang orang lain di akun media sosial seseorang. Media sosial seperti Faceook dan Instagram memungkinkan seseorang untuk mengaitkan atau menyertakan nama seseorang dalam postingan gambar atau poto dengan fitur tag yang tak terhitung yang diposting di situs-situs seperti Instagram, Flickr dan Facebook, dipoto dan diposting. Hal ini menimbulkan ketidaknyamanan bagi orang lain yang disertakan namanya apalagi bila dilakukan tanpa persetujuan orang tersebut. Penulis berpendapat, fitur tag adalah bentuk teknologi yang akan mengancam privasi seseoang karena memungkinkan pemaparan secara luas aspek kehidupan pribadi yang sebelumnya tertutup.

Masalah privasi ketiga
muncul seiring kecurigaan yang
meningkat tentang pengguna yang
sedang diselidiki dan tidak ada
informasi terkait pemafaatan data
pribadinya. MySpace, misalnya, pernah mengembangkan metode untuk memanen profil pengguna untuk informasi demografis yang dapat disediakan untuk pengiklan (Kafka 2007), sementara Hi5 menggunakan perangkat lunak yang disebut Zedo untuk menggabungkan informasi pribadi yang disediakan pengguna dengan alamat, kode pos, dan pendapatan pribadi untuk membuat profil konsumen yang sangat terperinci (2007).

Tanggapan survei dan komentar di forum menunjukkan bahwa respondeni menerima normalisasi pengawasan yang meningkat dan mengakui bahwa norma-norma seputar pengawasan dan privasi pribadi berubah. Mereka memiliki keprihatinan luas tentang 
kontrol mereka terhadap batasan privasi online, dan melaporkan penyensoran diri dan pengaturan akses, tetapi secara umum, mereka tidak mengetahui tingkat pengawasan yang dibagikan oleh Facebook, atau strategi khusus yang dapat digunakan untuk membatasi ancaman privasi tersebut. Sementara banyak yang merasa tidak nyaman dengan gagasan bahwa pemerintah dan lembaga penegak hukum dapat mengakses data mereka, dan bahwa pengusaha juga dapat melihat informasi pribadi mereka, sebagian besar pengguna menerima pengurangan dalam privasi adalah bagian dari kehidupan kontemporer, dan perlu untuk berpartisipasi dalam dunia online.

Pengguna Facebook secara rutin memantau orang lain dan sadar bahwa mereka pada gilirannya sedang dipantau, dan kesadaran akan pandangan orang lain mengarah pada modifikasi perilaku yang dirancang untuk mengelola batasan privasi (Locke 2010).

Janet M. Fulton \& Marjorie D. Kibby (2016) berujar, Privasi secara tradisional telah dilihat dalam hal 'hak' sehubungan dengan keamanan, keselamatan, ruang pribadi dan informasi pribadi. Generasi yang lebih tua, masih melihat privasi sebagai setara dengan kerahasiaan dan menjaga kerahasiaan pribadi dari pandangan publik, namun generasi milenium yang dikaji Janet dan Kibby cenderung melihat privasi sebagai komoditas, sesuatu yang dapat ditukar dengan teman online untuk modal sosial, dan diperdagangkan dengan organisasi untuk layanan dan manfaat. Sebagai komoditas, privasi dipandang sebagai sesuatu yang harus dikelola daripada dilindungi, dan pengawasan sistematis diterima sebagai bagian rutin dan tak terhindarkan dari kehidupan sehari-hari.

Sementara itu, Andrejevic menunjukkan bagaimana budaya baru "interaktivitas" media mengundang kita untuk dengan sukarela berpartisipasi dalam manipulasi kita sendiri dengan secara bebas memberikan informasi terperinci tentang diri kita kepada pemasar strategi pemasaran yang sangat difasilitasi oleh Internet, telepon seluler, dan teknologi DVR interaktif seperti TiVo. Berbeda sekali dengan janji utopis tentang teknologi media "interaktif" untuk demokrasi partisipatif, kenyataan dari apa yang disebut interaktivitas ini tampaknya tidak lebih dari bentuk pemantauan 
intensif yang bertujuan membantu pemasar mengembangkan bentuk persuasi konsumen yang lebih efektif dan efisien

Sissela Bok mendefinisikan privasi sebagai ranah dimana masalah pribadi dan kebebasan tidak dirusak (Brennen \& Primeaux, 1997, p. 23). Dari sudut pandang hukum, pengadilan telah memutuskan bahwa hak atas privasi adalah aspek mendasar dari budaya Barat. Di Amerika Serikat, Samuel Warren dan Louis D. Brandeis pertama-tama mengonsep privasi sebagai perumusan hukum dalam esainya tahun 1899: "The Right to Privacy'. Dengan demikian, hukum privasi fokus pada 'pelarangan terhadap gangguan yang mendalam pada martabat manusia oleh mereka yang memiliki kekuatan ekonomi atau pemerintahan' (Brennen \& Primeaux, 1997, p. 24). Bagaimana dengan Asia, termasuk Indonesia di dalamnya?

Dalam sebuah tulisan yang dilaporkan Lembaga Studi dan Advokasi Masyarakat (ELSAM) (06/07/2017),terminologi privasi secara lingustik tidak banyak dikenal di dalam budaya timur. Namun pada perkembangannya, beberapa negara Asia seperti Korea dan Singapura memiliki regulasi yang cukup ketat dan inovatif dalam rangka perlindungan hak atas privasi. Tujuannya tidak lain adalah untuk membangun ekosistem bisnis yang terpecaya termasuk bagi konsumen.

Privasi adalah fenomena spesifik budaya (Liang, Shen, \& Fu, 2017). Ketika media sosial menjadi global dan popular, pertanyaan mengenai praktik privasi dalam konteks lintas budaya menjadi semakin penting. Penelitian yag dilakukannya mengungkapkan perbedaan budaya dan masyarakat yang cukup besar dalam mempengaruhi perilaku pengguna media sosial dalam menggunakan pengaturan privasi di akunnya.

Penelitian lain yang menyebutkan adanya pengaruh budaya pada perilaku berbagi informasi dan privasi dilakukan oleh Nemati, Hamid, Jeffrey D Wall, dan Anthony Chow (2016). Budaya nasional di Amerika Serikat dan Cina, misalnya, memengaruhi sikap privasi pengguna terhadap teknologi pengungkapan diri dan memengaruhi penggunaan teknologi tersebut selanjutnya (Lowry et al., 2011). Berdasarkan temuan dalam penelitian sebelumnya (Lowry et al., 2011), peneliti berpendapat 
bahwa faktor budaya, politik, dan ekonomi di China dapat membuat pengguna media sosial Tiongkok lebih mungkin untuk berbagi informasi dan lebih sedikit menggunakan strategi koping privasi daripada pengguna A.S. Studi lintas-budaya menunjukkan bahwa budaya kolektivis di Tiongkok mengarahkan banyak pengguna Tiongkok untuk berbagi informasi dengan kelompok sosial mereka untuk menguntungkan kelompok-kelompok itu, sedangkan budaya individualistis di Amerika Serikat mengarahkan pengguna AS untuk berbagi informasi hanya ketika itu menguntungkan individu. Ini berarti bahwa pengguna dari budaya kolektivis, seperti Cina, mungkin lebih mungkin untuk berbagi informasi dengan anggota kelompok sosial mereka daripada pengguna dalam budaya individualistis (Lowry et al., 2011).

Dalam konteks media sosial, kecanduan internet dapat menyebabkan pengguna mengembangkan pintasan yang mencakup mengabaikan strategi penanggulangan privasi dan perlindungan privasi lainnya. Penelitian ini juga mengeksplorasi bagaimana persepsi negatif dan positif dari identitas online seseorang memengaruhi berbagi informasi dan perilaku penanggulangan privasi.

Fakta bahwa praktik berbagi pengguna media sosial tampaknya bertentangan dengan keprihatinan privasi mereka yang diungkapkan. Sehubungan dengan 'paradoks' ini, beberapa penulis menyimpulkan bahwa, untuk pengguna, ada perbedaan antara privasi sosial (mengendalikan mana orang-orang dalam jaringan mereka mendapatkan akses ke informasi mereka) dan privasi institusional (penggalian informasi pribadi oleh platform media sosial dan perusahaan komersial lainnya) dan bahwa kekhawatiran pengguna media sosial tentang pengontrolan informasi pribadi mereka berhubungan dengan yang pertama, bukan yang terakhir (Raynes-Goldie 2010; Young and Quan-Haase 2013).

Sehubungan dengan Facebook, masalah privasi utama bukanlah seberapa banyak informasi yang disediakan pengguna kepada publik, melainkan: data pengguna mana yang digunakan oleh Facebook untuk tujuan periklanan; di mana para pengguna dieksploitasi dalam proses ini; dan bagaimana pengguna dapat dilindungi dari konsekuensi negatif pengawasan ekonomi di Facebook. 
Menurut Fuchs, Pengawasan di

Facebook bukan hanya proses interpersonal, tapi pengawasan ekonomi, yaitu pengumpulan, penyimpanan, penilaian, dan komodifikasi data personal, perilaku penggunaan, dan data yang dibuat pengguna untuk tujuan ekonomi. Di Facebook, perusahaan mengumpulkan semua data pribadi dan perilaku pengguna dan mengkomodifikasi keduanya, sambil menyembunyikan proses ini dari pengguna. Pengguna hampir tidak bisa melindungi dirinya dari proses komoditas ini.

Menurut Fuchs, Privasi sesungguhnya konsumen, pekerja, dan prosumer hanya dimungkinkan dalam demokrasi partisipatif. Maka itu, Fuchs mengusulkan konsepsi privasi dari politik privasi internet sosialis. Ini dilakukan untuk mendorong kembali modifikasi data-pengguna dan eksploitasi prosumen dengan memajukan dekomodifikasi internet. Tiga strategi untuk mencapai tujuan ini adalah kemajuan iklan online optin, pengawasan masyarakat sipil terhadap perusahaan internet, dan pembentukan dan dukungan platform alternatif.

\section{Sinisme Privasi}

Turow dkk. (2015b) dalam kaitannya dengan pengawasan menunjukkan Orang bersedia memperdagangkan datanya demi mendapatkan akses dan layanan. ini yang disebut oleh Turrow sebagai ' tradeoff fallacy' —orang merasa pasrah terhadap penambangan data, melihatnya sebagai praktik yang tidak dapat mereka kendalikan. Namun pengguna memiliki perhatian dan kekuatiran besar manakala data pribadi mereka dibagikan, data ditambang tanpa persetujuan, dan transparansi yang tidak memadai tentang data mereka yang diawasi dan ditambang.

Meski demikian, menurut Christian Hoffman et al. (2016), ketika individu kewalahan oleh ancaman terhadap kemampuan mereka untuk mengontrol bagaimana institusi mengakses dan menggunakan data pribadi mereka, mereka mengembangkan sikap yang penulis sebut "sinisme privasi." Berdasarkan pada kelompok fokus dengan pengguna internet di Jerman, penulis berpendapat bahwa sementara individu mengenali risiko terhadap privasi informasi mereka, mereka juga menggambarkan kurangnya kekuatan atas situasi tersebut. Mereka 
mendefinisikan sinisme privasi sebagai "suatu sikap ketidakpastian, ketidakberdayaan dan ketidakpercayaan terhadap penanganan data pribadi oleh layanan online, menjadikan perilaku perlindungan privasi secara subyektif sia-sia" (Hoffman et al., 2016). Mirip dengan Turow et al. (2015), Hoffman et al. menemukan kesadaran yang lebih besar tentang risiko privasi sesuai dengan perasaan ketidakberdayaan yang lebih kuat (lihat juga Xie et al., 2018). Pengunduran diri tidak menunjukkan pengunduran diri sepenuhnya dari upaya untuk melindungi diri dari pengawasan perusahaan.

Sebagai contoh, sebuah laporan Pew Research Center 2016 mengungkapkan bahwa lebih dari separuh pengguna Internet di Amerika Serikat telah "mengambil langkahlangkah untuk menghindari pengawasan oleh orang-orang tertentu, organisasi atau pemerintah" dengan alas an bahwa itu "sangat penting" bagi mereka untuk mengendalikan siapa yang dapat mengakses dan mengumpulkan data dan informasi mereka (Rainie, 2016). Namun, laporan yang sama menggambarkan lebih dari $90 \%$ orang Amerika setuju bahwa "konsumen telah kehilangan kendali tentang bagaimana informasi pribadi dikumpulkan dan digunakan oleh perusahaan." Dalam sebuah studi tentang aktivis sosial di Inggris, Lina Dencik et al. (2016) mengamati ketergantungan pada platform komunikasi arus utama yang membatasi opsi untuk meningkatkan perlindungan privasi. Penelitian menggambarkan para peserta yang kuatir tentang pelacakan perilaku dan pengumpulan data, dan pada saat yang sama bergantung pada platform di mana praktik-praktik ini berlangsung untuk mendukung kegiatan mereka di media sosial.

\section{Diskriminasi \\ Apa aspek lain dari} penggunaan media sosial tidak begitu terlihat? Satu jawaban untuk pertanyaan ini berkaitan dengan bagaimana pengawasan baru di era internet memilah, mendiskriminasi, dan membentuk struktur kehidupan sosial.

Dalam buku The Daily You: How the New Advertising Industry Is Defining Your Identity and The Worls (2012), Turow berpendapat bahwa pengawasan data serta penambangan data yang dilakukan industri-industri 
ini mengarah pada diskriminasi sosial.

Ini terjadi karena, melalui proses analisis data, 'profil individu' diubah menjadi 'evaluasi individu' .Perhitungan nilai pemasaran setiap orang dihasilkan, berdasarkan pada perilaku dan bentuk-bentuk lain dari pelacakan data, dan masing-masing individu dikategorikan sebagai target atau pemborosan. Turow berargumen, pengawasan dan penggalian data tidak hanya menentukan apa yang dilakukan oleh perusahaan pemasaran tetapi juga bagaimana kita melihat diri kita sendiri dan orang lain. Kita yang dianggap "kaya dan boros" menerima opsi-opsi yang menyempit dalam pesan iklan yang ditargetkan pada kita, dan, menurut Turow, ini berdampak pada perasaan kita.

Beer and Burrows (2013) menunjukkan cara di mana diskriminasi data beroperasi dalam aspek budaya lainnya. Menulis tentang cara di mana teknologi konsumsi musik menghasilkan data yang dapat diarsipkan tentang kebiasaan konsumsi (jenis musik apa yang dikonsumsi, seberapa sering dan untuk berapa lama, lokasi geografis dari praktik konsumsi), mereka memetakan bagaimana data ini memainkan peran dalam membentuk perangkat keras, perangkat lunak, dan perdagangan konsumsi musik dengan berbagai cara. Mereka berpendapat bahwa data tentang praktik mendengarkan memberi makan production produksi sistem geodemografi nasional skala besar yang pada gilirannya memberikan analisis tingkat kode pos tingkat selera dan preferensi orangorang '(2013, hal. 59). Dengan demikian, data merupakan lebih dari sekadar budaya, juga berfungsi untuk membentuk rezim tata kelola dan kontrol. Di tempat lain, menulis secara spesifik tentang analisis sentimen, Hearn berpendapat bahwa kemampuan penambangan data untuk mengidentifikasi sentimen berharga merupakan mekanisme ekstraksi nilai kapitalis yang lain. Dia menggambarkan orang-orang yang melakukan pekerjaan ini sebagai 'perantara perasaan', yang 'menyusun perasaan menjadi keuntungan untuk diri mereka sendiri dan klien mereka' (2010, hlm. 435-43). Demikian juga Andrejevic (2011) prihatin tentang peran yang dimainkan oleh sentimen media sosial dalam prediksi dan pengendalian pengaruh, yang ia gambarkan, mengutip Massumi, sebagai 'variabel intrinsik dari sistem kapitalis akhir, sebagai infrastruktur 
sebagai pabrik' (Massumi 2002, hal. 45, dikutip dalam Andrejevic 2011, hal. 609).

Lev Manovich sependapat, yang menyatakan bahwa 'hanya perusahaan media sosial yang memiliki akses ke data sosial yang sangat besar. Seorang antropolog yang bekerja untuk Facebook atau seorang sosiolog yang bekerja untuk Google akan memiliki akses ke data yang tidak akan diterima oleh komunitas ilmiah lainnya '(Manovich 2011, p. 5). Tanpa ragu, perusahaan komersial elit seperti Google, Facebook dan Amazon memiliki akses terbaik ke data, serta alat dan metode terbaik untuk memahami itu (Williamson 2014); beberapa perusahaan bahkan telah mengecilkan hati para akademisi dari meneliti media sosial. Beberapa perusahaan membatasi akses ke data sepenuhnya, yang lain menjual akses dengan biaya tinggi, beberapa menawarkan set data kecil untuk peneliti berbasis universitas. Jadi mereka yang memiliki uang atau di dalam perusahaan memiliki akses diferensial data media sosial untuk mereka yang tidak memiliki sumber keuangan yang diperlukan untuk memperolehnya. boyd dan Crawford (2012) berpendapat bahwa, mengingat tren ini, segera hanya universitas tingkat atas, sumber daya yang baik akan dapat menegosiasikan akses ke sumber data komersial, dan siswa dari elit, universitas papan atas cenderung menjadi yang diundang untuk bekerja di dalam perusahaan media sosial, memperburuk pola ketidaksetaraan yang ada.

Jadi akses ke data, penambangan data, dan keterampilan untuk melakukannya tidak merata dan ini mengarah pada pembagian digital baru. Dengan demikian, Boyd dan Crawford (2012) memperingatkan bahwa ada bahaya data besar yang besar dan buruk muncul terkait dengan akses data, alat, keterampilan, dan keahlian. Tetapi mengapa akses seperti itu penting? Boy dan Crawford berujar, kriteria penting 'demokratisasi efektif' dapat diukur dari 'partisipasi dan akses ke arsip, konstitusi, dan interpretasinya.

Bentuk diskriminasi lain yang dilakukan Media sosial khususnya Facebook dijabarkan Sarah Myers West (2017). Dengan dalih mengatasi akun dengan nama samaran dan anonimitas, Facebook mengharuskan pengguna mendaftar dengan nama "asli". Selain itu penciptaan fitur pelaporan otomatis yang 
memungkinkan pengguna yang melanggar kebijakan untuk ditandai oleh pengguna lain telah mengakibatkan diskriminasi luas terhadap komunitas tertentu, termasuk anggota komunitas trans-gender dan penduduk asli Amerika yang akunnya ditutup berdasarkan klaim bahwa mereka tidak menggunakan nama asli mereka.

\section{Objek Komoditas Data}

Tanpa banyak pengguna sadari, media sosial mengubah informasi pribadi orang menjadi aliran pendapatan jaringan itu sendiri. Facebook menghasilkan sebagian besar uangnya dengan menjual ruang iklan di situsnya dan membantu pengiklan mempersonalisasikan iklan mereka dan mengarahkannya ke anggota tertentu dengan menggunakan informasi dari profil dan entri anggota Facebook. Pengiklan memilih kata kunci atau detail- seperti status hubungan, lokasi, minat, aktivitas, buku favorit, demografi, informasi ketenagakerjaan - dan kemudian Facebook menjalankan iklan untuk pengguna yang ditargetkan. EMarketer memperkirakan bahwa Facebook memperoleh \$1,86 miliar pendapatan iklan di 2010. Facebook juga menghasilkan uang melalui perjanjian pembagian pendapatan dengan perusahaan yang menawarkan lebih dari 550.000 aplikasi yang berjalan di situs, termasuk game seperti Mafia Wars dan FarmVille. Pada tahun 2011, Facebook mengatakan kepada semua pengembang game bahwa mereka akan diminta untuk menerima pembayaran melalui mata uang baru jejaring sosial, Kredit Facebook. Ini tentunya berdampak signifikan pada pendapatan Facebook karena Facebook akan menyimpan 30\% dari jumlah kredit, memperoleh cukup besar sebagian dari setengah miliar dolar yang diperoleh setiap tahun oleh aplikasi.

Apa yang dilakukan Facebook disebut West (2017) sebagai Kapitalisme data. West merujuk pada penjelasan Zuboff (2016) yang memperkenalkan konsep surveillance capitalism/kapitalisme pengawasan. Menurut Zuboff, di jaman digitalisasi seperti sekarang, ada pihak yang lebih kuat dan lebih canggih dibandingkan dengan institusi negara dalam melakukan pengawasan atau tindakan mata-mata. Institusi pengawasan yang dimaksud adalah korporasi swasta yakni perusahaan-perusahaan platform 
digital. Alasan atau motivasi pengawasan tersebut, menurut Zuboff dan West bukan semata karena alasan politik ataupun ideologis, melainkan demi tujuan bisnis atau ekonomi. Pada konteks pengawasan tersebut, hampir setiap orang tanpa terkecuali menjadi objek mata-mata/pengawasan, alasannya bukan karena kita membahayakan namun kita dibutuhkan oleh pemasok data dan objek periklanan platform-platform digital di atas.

Penulis berpendapat, kehadiran kita di media sosial sangat didambakan oleh pemasok data. Media sosial sebagai salah satu platform digital tersebut memungkinkan di mana data kita dikomodifikasi melalui redistribusi kekuasaan di era informasi. Facebook memperoleh keuntungan dari menghimpun informasi mengenai orang yang menggunakan media sosialnya. Kelihatannya, media sosial itu gratis, tapi sesungguhnya kita 'membayar' dengan informasi tentang diri kitanama, alamat email, nomor handphone. Monetisasi data adalah langkah berikutnya setelah penambangan data dilakukan yang merupakan bagian 'permainan jangka panjang'. Apa yang dimainkan
Facebook kemudian menjadikan pengguna internet sebagai target iklan online. Permainannya adalah menjual akses kepada 'aliran real-time' dari kehidupan sehari-hari. Data behavior/data pribadi sehari-hari terus diawasi: kapan dan di mana mengakses internet, berbelanja online, membeli makanan melalui layanan pesan-antar, dst. Dari data perilaku tersebut, perusahaan memiliki sekumpulan data yang digunakan untuk menganalisis 'profil Anda' dan kemudian memodifikasi perilaku Anda demi memperoleh keuntungan. Semua itu merupakan 'pintu masuk' ke dalam dunia baru peluang-peluang monetisasi. Kapitalisme telah dibajak oleh proyek 'pengawasan' yang menguntungkan sebagian orang.

\section{KESIMPULAN}

Platform media sosial memungkinkan penggunanya untuk saling berkomunkasi, berbagi informasi dengan pengguna lain, termasuk perincian data pribadi mereka sendiri. Sementara, aktor negara dan perusahaan memiliki potensi untuk mengawasi dan mengintervensi platform ini. Konsekuensi sosial tidak hanya hilangnya privasi, tetapi juga 
diskriminasi, penyortiran sosial dan komodifikasi data. Pada media sosial, pengguna merasa bahwa konten mereka bersifat pribadi, meskipun secara teknis, tidak. Pelaku pengawasan sendiri memandang media sosial sebagai ruang publik.Dengan kemunculan konsekuensi sosial tersebut, penulis meminjam pemikiran Fuchs untuk perlunya pengawasan masyarakat sipil terhadap perusahaan internet, dan pembentukan dan dukungan platform alternative sebagai kontra pengawasan yang tidak simetris yang dilakukan oleh raksasa-raksasa digital.

\section{Daftar Pustaka}

Andreas, Kaplan M., Haenlein Michael 2010. "Users of the world, unite! The challenges and opportunities of social media". Business Horizons

Andrejevic, Mark. 2007. "Surveillance in the Digital Enclosure." The Communication Review 10 (4): 295-317. doi:10.1080/1071442070171536 5.

Andrejevic, Mark, and Mark Burdon. 2015. "Defining the Sensor
Society." Television and New

Media 16 (1): 19-36. doi:10.1177/1527476414541552

Andrews Lori.2013. I Know Who You Are and I Saw What You Did: Social Networks and the Death of Privacy Andrews Lori . Free Press .Newyork America

Boyd, d., \& Hargittai, E. (2010). Facebook privacy settings: Who cares? First Monday, 15(8). http://dx.doi.org/10.5210/f $\underline{\text { m.v15i8.3086 }}$

Brown, Brian A. 2013. "Primitive Digital Accumulation: Privacy, Social Networks, and Biopolitical Exploitation." Rethinking Marxism 25 (3): 385-403. doi:10.1080/08935696.2013.798 974.

Fuchs, Christian. 2012. "The Political Economy of Privacy." Television \& New Media 13 (2): 139-59.

Fuchs, Christian. 2011. "Towards an Alternative Concept of Privacy." Journal of Information, Communication and Ethics in Society 9 (4): 220-37. 
Fuch Chriatian, Kees Boersma, Anders Albrechtslund, Marisol Sandoval (editors).2012. Internet and surveillance the challenges of Web 2.0 and social media. Routledge studies in science, technology and society

Fulton, Janet M., and Marjorie D. Kibby. 2017. "Millennials and the Normalization of Surveillance on Facebook." Continuum 31 (2). Routledge: 189-99. doi:10.1080/10304312.2016.126 5094

Hoffmann, C. P., Lutz, C., \& Ranzini, G. (2016). Privacy cynicism: A new approach to the privacy paradox. Cyberpsychology: Journal of Psychosocial Research on Cyberspace, 10(4), article 7. http://dx.doi.org/10.5817/CP201 6-4-7

Jørgensen, Rikke Frank, and Tariq Desai. 2017. "Right to Privacy Meets Online Platforms: Exploring Privacy Complaints against Facebook and Google." Nordic Journal of Human Rights 35 (2). Taylor \& Francis: 106-26.
Kelly, Louise, Gayle Kerr, and Judy Drennan. 2017. "Privacy Concerns on Social Networking Sites: A Longitudinal Study." Journal of Marketing Management 33 (17-18). Routledge: 1465-89. doi:10.1080/0267257X.2017.140 0994

Lyon, David. 2017. "Surveillance Culture: Engagement, Exposure, and Ethics in Digital Modernity." International Journal of Communication (Online) 11: 824. doi:1932 - 8036/2017000 5.

\section{Manuel Castell:Communication} Power,Oxford:Oxford University Press.20019

Nemati, Hamid, Jeffrey D Wall, and Anthony Chow. 2016. "Privacy Coping and Information-Sharing Behaviors in Social Media: A Comparison of Chinese and U . S - Users Privacy Coping and Information-Sharing Behaviors in Social Media: A Comparison of Chinese and U. S. Users" 6846 (March). doi:10.1080/1097198X.2014.978 622. 
Solove, Daniel J. 1970. "Introduction : Privacy Self-Management and the Consent Dilemma" 1880: $1880-1903$.

Specht, Doug. 2017. "Undressing with the Lights On: Surveillance and The Naked Society in a Digital Era ." 12: 78-90. Group: 75-89. doi:10.1057/jit.2015.5.

Sudibyo, Agus Rezim Pengaturan Digital.20 Agustus 2018. Kompas

Turow, Joseph, Lee McGuigan, and Elena R. Maris. 2015. "Making Data Mining a Natural Part of Life: Physical Retailing, Customer Surveillance and the 21st Century Social Imaginary.” European Journal of Cultural Studies 18 (4-5): 464-78. doi:10.1177/1367549415577390.
Van Dijck, J. 2013a. The Culture of Connectivity. Oxford: Oxford University Press

West, Sarah Myers. 2017. "Data Capitalism: Redefining the Logics of Surveillance and Privacy." West, Sarah Myers. 2017. "Data Capitalism: Redefining the Logics of Surveillance and Privacy."Business \& Society, 000765031771818.

Doi:10.1177/0007650317718185

Zuboff, Shoshana. 2015. "Big Other: Surveillance Capitalism and the Prospects of an Information Civilization." Journal of Information Technology 30 (1). Nature Publishing 